\title{
Safflower grown in different sowing dates and plant densities
}

\author{
Cultivo de cártamo em diferentes épocas de semeadura e densidade de plantas
}

\section{Rogério Antonio Bellé ${ }^{I *}$ Edileusa Kersting da Rocha ${ }^{\mathrm{I}}$ Fernanda Alice Antonello Londero Backes ${ }^{\mathrm{I}}$ Mauricio Neuhaus ${ }^{I}$ Natalia Teixeira Schwab ${ }^{\mathrm{I}}$}

\begin{abstract}
The objectives of this study were to test the effects of different plant densities on stem characteristics in two growing seasons: Fall/Winter and Spring/Summer. The plant densities evaluated were 48, 64, 80, 96, 112 and 128plants $\mathrm{m}^{-2}$. The Fall Winter growing season was from 04/04/2008 to 23/08/2008 and the Spring/Summer growing season was from 03/10/2008 to 23/ 12/2008. Total and partial plant height did not differ among plant densities in the Fall/Winter growing season. However, in the Spring/Summer growing season total plant height had a quadratic response to increase in plant population whereas the partial height did not vary. In the Fall/Winter cultivation, plants presented larger stems and branches diameter, branches length and total number of nodes main stem and branches diameters, number and length of branches, fresh and dry mass decreased as density increased in the two growing seasons. The capitulum's diameter decreased as density increased in the Fall/Winter growing season, but at the Spring/Summer growing season it decreased in the density from 48 to 96plants $\mathrm{m}^{-2}$ and increased in the density from 112 a 128plants $\mathrm{m}^{-2}$.
\end{abstract}

Key words: Carthamus tinctorius, stem quality, floriculture.

\section{RESUMO}

Este trabalho teve como objetivos testar diferentes densidades da cultura do cártamo, quanto às características da haste em duas épocas de cultivo: outono/inverno $e$ primavera/verão. As densidades utilizadas nas duas épocas foram 48, 64, 80, 96, 112 e 128plantas $\mathrm{m}^{-2}$. O cultivo de outono/inverno correspondeu ao período de 04/04/2008 a 23/ $08 / 2008$ e o cultivo de primavera/verão correspondeu ao período de 03/10/2008 a 23/12/2008. As alturas total e parcial não apresentaram diferenças significativas entre as densidades no cultivo de outono/inverno. Já na primavera/verão, a altura total apresentou comportamento quadrático com o aumento da densidade e a altura parcial não variou. No cultivo de outono/inverno as plantas apresentaram maiores valores de diâmetro da haste, diâmetro dos ramos, comprimento de ramos e maior número total de nós. O diâmetro da haste, diâmetro dos ramos, número e comprimento dos ramos, a massa fresca e a massa seca decresceram com o aumento da densidade nas duas épocas de cultivo. O diâmetro do capítulo decresceu com o aumento da população no outono/inverno, mas na primavera/verão decresceu nas densidades de 48 a 96plantas $m^{-2}$ e aumentou nas densidades de 112 a 128 plantas $m^{-2}$.

Palavras-chave: Carthamus tinctorius, qualidade de haste, floricultura.

\section{INTRODUCTION}

The safflower (Carthamus tinctorius L.), belonging to the Asteraceae family, it is extensively grown in many countries as an oil crop (OELKE et al., 2010). However, there are cultivars that can be grown for flower production but little is known on these cultivars in Brazil (OLIVEIRA, 2007). Therefore this crop can be a new alternative for flower producers in Rio Grande do Sul State, as fresh or dried flowers, since it is adapted to cooler climate, and so increase the diversity of flowers propagated by seeds (STRECK et al., 2005).

BURKANT (1974) describes safflower as being a successor of saffron in cooking, and it is grown both as annual plant and for oil. The latter author also describes the plant as having a flat receptacle, covered with petals, isomorphic with flowers, all hermaphrodites, with tubular corollas of pentaseptate limbo. The stamens have filaments at the middle and sagittate anthers at

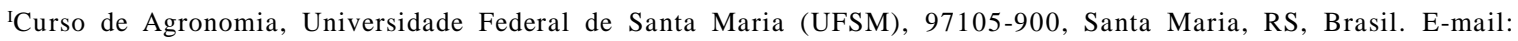
rogeriobelle@gmail.com. *Autor para correspondência. 
the base. The seeds are tetragonal, hairless, the alternate leaves are toothed or lobed and the capitula are large, solitary and located at the apex of branches. Flower colors can be yellow, orange, purple or white. In cultivars with yellow capitula at the opening stage, the inflorescences become darker as the plant get old (BELLÉ, 2008).

In Europe, this specie is cultivated as an ornamental crop and there are cultivars developed specifically for this purpose. In Germany, the flower cultivars Carthamus Oranje, Donkeoranje Select and Carthamus Summersun are sown in mid-July to September (Summer/Fall) and are used 250 to $300 \mathrm{~g}$, or about 6,000 seeds, to form a $100 \mathrm{~m}^{2}$ plant bed (60plants $\mathrm{m}^{-2}$ ) (SNIJBLOEMENKATALOGUS, 1996) are required.

Orange Grenade, described as an early cultivar is very attractive and suitable for fresh and dried bouquets, Orange is heavily branched and ideal for gardens, and Yellow Grenade are sown in the Netherlands in April-May (Spring), directly in the soil. In order to seed a $420-490 \mathrm{~m}^{2}$ area to obtain 27 to 31 plants $\mathrm{m}^{-2}, 1000 \mathrm{~g}$ of seeds are necessary and $75 \mathrm{~g}$ contains about 1,000 seeds (MULLER FLOWERSEEDS, 1998).

In Brazil, three ornamental cultivars of safflower (Sakata Seed) have been available: Lasting Orange that is yellow when opens and later changes to orange, White Lasting that is ivory white and Lasting Yellow that has pure yellow flowers. These cultivars, can be sown all year round and harvested at around 90 days after sowing. They are 80 to $90 \mathrm{~cm}$ tall and the flowers are about $3.5 \mathrm{~cm}$ in diameter. The ideal temperature to grow this plant is $20^{\circ} \mathrm{C}$ and the emergence period ranges from 7 to 10 days (SAKATA, 2010). Although these cultivars are available and grow commercially, there is not a recommended target plant density, that maximizes yield and quality which constituted a rationale for this study.

GIAYETTO et al. (1999), using a density of 143,000plants ha ${ }^{-1}$ and during two years, 1990 and 1991, studied the response and adaptability of different oil safflower varieties. They observed that the phenological stages, when the plant was more susceptible to cold were stem elongation and flowering. Just after sowing and plant emergence, soil water deficit is critical and decreases plant initial density. In 1991, the same authors observed a greater plant height $(113 \mathrm{~cm})$ than the year before, when average height was $74 \mathrm{~cm}$. This difference was attributed to a longer duration of the vegetative phase, which includes the rosette and elongation stages, and to a low rainfall during stem elongation. The plant life cycle ranged from 201 days in 1990 up to 239 days in 1991, and the percentage of oil in achenes was above $33 \%$ in both years.
It is known that maximizing plant density can result in higher seed yields. However, these density may not be the most appropriate when the goal is the production of flowers because there is no need to complete de plant life cycle in the latter. Also, depending on the sowing season, climatic factors can interfere directly on the quality parameters of the stems.

HOLCOMB \& MASTALERZ (1979) studied the response of four chrysanthemum cultivars at 26, 52, 104 and 207plants $\mathrm{m}^{-2}$ during four years. They observed that the stem length was longer when the density increased from 26plants $\mathrm{m}^{-2}$ to 52 plants $\mathrm{m}^{-2}$, probably due to competition between plants for light. However, when the density increased from 52plants $\mathrm{m}^{-2}$ to 104 plants $\mathrm{m}^{-2}$ there was no effect on stem length, but a reduction in shaft length was observed when plant density increased from 104 to 207plants $\mathrm{m}^{-2}$. This decrease was attributed to an increased competition for water, nutrients and light. They also observed that flower diameter and quality decreased as plant density increased during all years tested.

HOEVEN et al. (1975) evaluated during two growing seasons, different densities of chrysanthemum, variety 'Spider' (Winter: 22, 26, 32, 38, 43 and 48plants m $^{-2}$; Summer/Fall: 32, 43, 48, 56 and 64plants $\mathrm{m}^{-2}$ ) and found that in both seasons, with the increase of density, the stem fresh mass and number of flowers per stem decreased but the length of the stem did not change.

The development of growing techniques can improve the quality imposed by the sowing season associated with plant population and thus provide important advances in the improvement of the flowers, resulting in higher prices and greater appreciation of bouquets and floral arrangements. Thus, the objective of this study was to test different plant densities of safflower during two growing seasons (Fall/Winter and Spring/Summer), in order to generate useful information for farmers.

\section{MATERIAL AND METHODS}

This study was conducted inside a polyethylene plastic greenhouse measuring $8.0 \mathrm{~m}$ wide by $15.0 \mathrm{~m}$ long and $2.5 \mathrm{~m}$ height at the Departamento of Fitotecnia, Universidade Federal de Santa Maria. The experimental design was a randomized block with four replications.

Two experiments were carried out during two growing seasons with Carthamus tinctorius L. variety Lasting Orange. The first season (Fall/Winter) was from 04/04/2008 to 23/08/2008 (141 days), and the second season (Spring/Summer) was from 03/10/2008 to 22/12/ 2008 (80 days). In each growing season six plant densities were tested: 48, 64, 80, 96, 112 and 128plants $\mathrm{m}^{-2}$. 
The plant beds were one meter wide and seven meters long. The seeds were treated with fungicide (Thiram), and sown directly into the soil. After sowing, the maximum and minimum temperatures inside the greenhouse were measured daily until the end of harvest. Plants were irrigated daily with a drip system irrigation distributed along the plant beds. To maintain the plants upright, lateral screens were maintained until the plants were $0,90-1,0 \mathrm{~m}$ tall.

The following evaluations were performed: total height of plant, partial plant height, total number of nodes, stem diameter, number of branches, branch length and diameter, capitulum's diameter and, fresh and dry stem mass. These variables were sampled in ten plants per replicate which were randomly selected at the beginning of the experiment.

Total height was measured from the soil surface to the longest branch and partial height from soil surface to the main inflorescence. Both were measured at harvest and the plants were cut in the neck hereafter called stem.

The nodes visible from soil surface up to capitulum insertion, including branch nodes, were recorded. Stem diameter was measured at three different heights: insertion of the last branch, and $20 \mathrm{~cm}$ and $60 \mathrm{~cm}$ from the last branch. The number of branches on each stem and the length of each branch from its insertion to the branch on stem up to the inflorescence attachment were measured.

Average branch diameter was obtained at three positions: at the bottom, middle and at the apex. Because of difficulty to obtain capitulum diameter, due to its irregular formation, the circumference of the central part of the capitulum was taken. Stem fresh and dry mass were obtained by weighting fresh stem samples and after drying them in oven at $60^{\circ} \mathrm{C}$ to $70^{\circ} \mathrm{C}$ until constant mass.

Statistical analysis was performed considering Fall/Winter and Spring/Summer growing seasons separately, and a regression analysis considered plants density as the independent variable.

\section{RESULTS AND DISCUSSION}

The analysis of variance indicated that in the Fall/Winter growing season, there were no significant differences for the variables total and partial plant height among the plant densities (Figure 1). Similar results were reported by NARDI et al. (2001) and HOEVEN et al. (1975) when testing different density and chrysanthemum cultivars in two growing seasons. However, HOLCOMB \& MASTALERZ (1979), observed differences in length of chrysanthemum stems when plant population varied, with an increase in stem length as population varied from 26plants $\mathrm{m}^{-2}$ to 52plants $\mathrm{m}^{-2}$, and a reduction when the population increased from 104plants $\mathrm{m}^{-2}$ to 207plants $\mathrm{m}^{-2}$.

Comparing total height and partial plant height (Figure 1A in the Fall/Winter season) it can be observed that the partial height was less than total height. This result indicates that the main capitulum is located at a lower level than other capitulum, and from a commercial point of view, this is not a desirable trait. The same type of trait can be observed in many chrysanthemum cultivars, and the solution is to eliminate the main flower. This result suggests that safflower breeding should continue in order to reduce these differences, managing to avoid elimination main flower.

The total number of nodes decreased from $29.36 \%$ in Fall/Winter growing season, reducing from 73.90 nodes per plant at 48 plants $\mathrm{m}^{-2}$ to 52 nodes at 128 plants $\mathrm{m}^{-2}$. This reduction was also observed in the Spring/Summer growing season with a 26.94\% reduction, from 62.90 to 45.95 nodes per plant (Figure 1B).

The reduction in the number of nodes from one growing season to another is probably related to combinations of factors. Firstly reducing the number of nodes of the main stem may by a response to photoperiod, as a plant is responsive to photoperiod (DAJUE \& MÜNDEL, 1996). Variations in the number of nodes related to photoperiod were also found in soybeans (MARTINS et al, 2011). Second by reducing the number of branches from the lowest to the highest density, represented by a linear decrease in the number of nodes. Differences in the total number of nodes between the growing seasons ranged from 6 to 11 , values that are related to the reduction on the number of nodes on the main stem in the second sowing season. This difference in total node number (6 to 11) could also be attributed, in part, to changes in the number of branches between growing seasons.

In the Fall/Winter growing season, there was a $2.76 \mathrm{~mm}$ decrease in stem diameter, from $7.89 \mathrm{~mm}$ in the density of 48plants $\mathrm{m}^{-2}$ to $5.12 \mathrm{~mm}$ in the 128 plants $\mathrm{m}^{-2}$ plant population. The same was observed in the Spring/ Summer growing season, when the average reduction was $2.21 \mathrm{~mm}$, decreasing from 6.68 to $4.47 \mathrm{~mm}$ when comparing to the greatest population (Figure 1C).

The decrease in stem diameter as population increased may be associated with greater elongation of internodes, due to competition for solar radiation. However, it seems that in the Fall/Winter growing season, when solar radiation was lower, stem diameter was larger compared with at Spring/Summer growing season, when solar radiation was greater. It was visually observed that leaves were considerably larger during the Fall/Winter growing season, which may have contributed to this advantage in diameter, as the plant life cycle was longer and a compensation may have occurred resulting in an increase in assimilate 


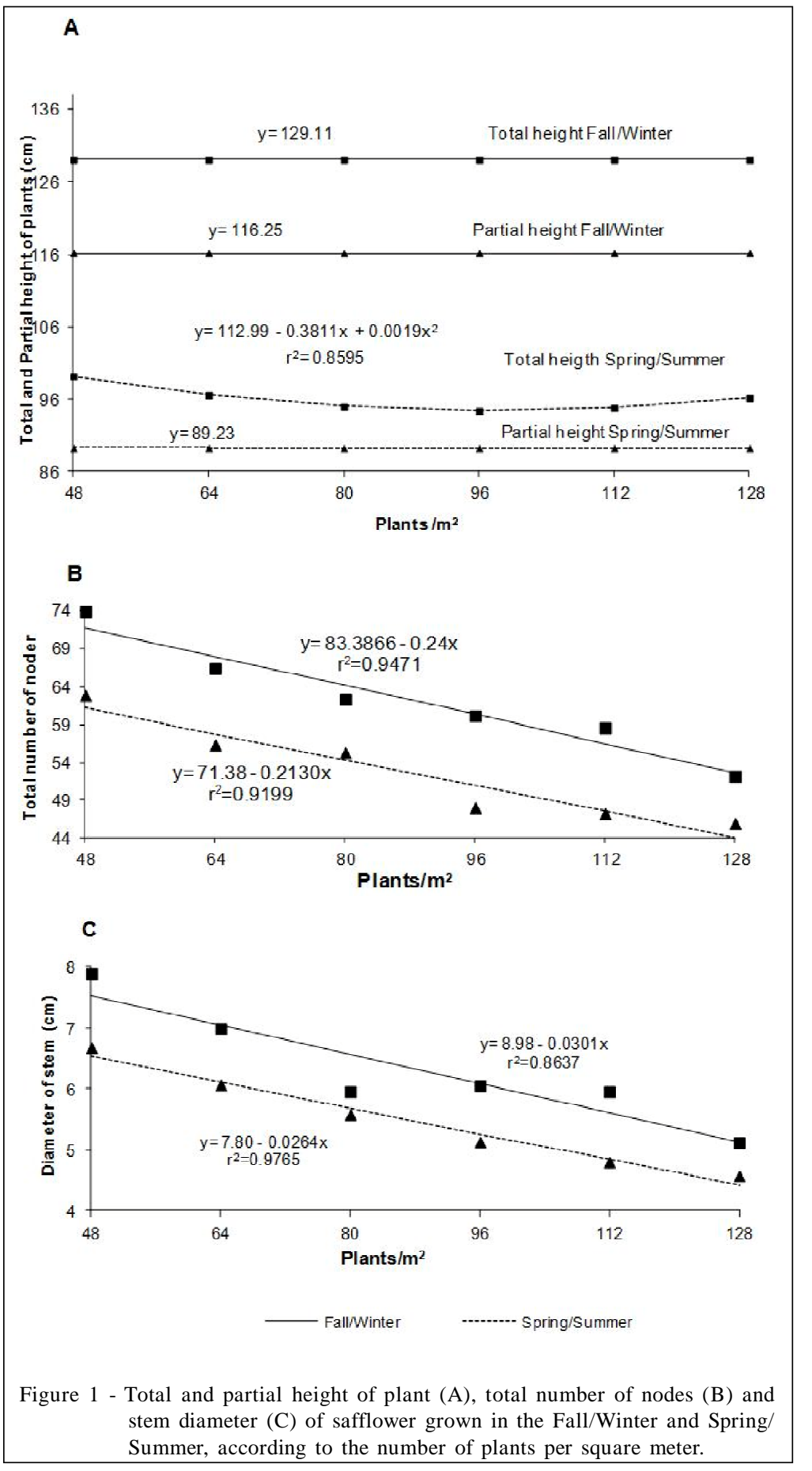

production according to ANDRIOLO (1999), when there is surplus of assimilates, these are temporarily stored in the leaves and stem, which may have caused an increase in the structures.

Stem diameter is an important characteristic when assessing stem quality through its degree of rigidity. NARDI et al. (2001) observed a significant decrease in stem quality due to a decrease of stem diameter in chrysanthemum, because it resulted in high flexibility, which leads to easy breaking. In the case of safflower, no excessive flexibility and breaking were observed, although it had slender stalks at higher density, but they were well lignified and resilient. 
The number of branches produced at different densities is an important quantitative factor in determining quality of flower stems, that is, the greater the number of branches, the greater the number of inflorescences. For safflower, there isn't interest in obtaining stems with lots of branches, because of differences in flowering rates within the capitulum. Many branches result in lack of uniformity in anthesis, which reduces stems quality.

In the Fall/Winter growing season, there was a $35 \%$ reduction in the number of branches, from 4.25 at the 48 plants $\mathrm{m}^{-2}$ to 2.75 branches at plant density of 128plants $\mathrm{m}^{-2}$ (Figure 2A). Also, there was an increase in branch length that averaged $35.88 \mathrm{~cm}$ at the density of 48 plants $\mathrm{m}^{-2}$, but at the density of 128 plants $\mathrm{m}^{-2}$ branch length decreased $36.7 \%$, to $22.71 \mathrm{~cm}$ (Figure 2B).

A greater reduction, both in number of branches and length of branches, was observed during the Spring/Summer growing season (Figure 2A). The number of branches decreased approximately $41 \%$, down from 4.75 to 2.8 branches per plant (Figure 2B). Length of branches decreased $44 \%$, with the longest branches

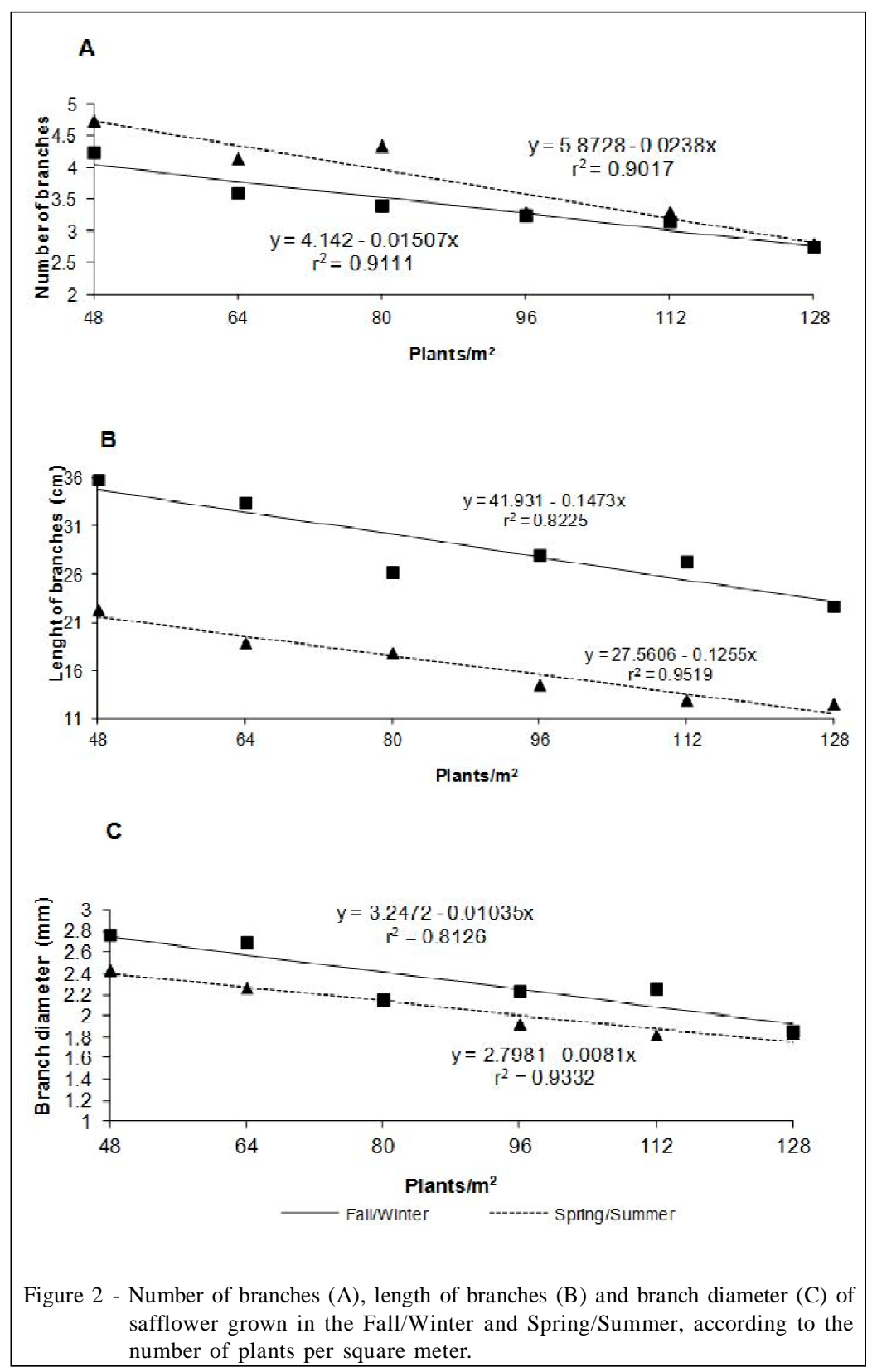

Ciência Rural, v.42, n.12, dez, 2012. 
obtained at lowest density $\left(22.35 \mathrm{~cm}\right.$ at 48 plants $\left.\mathrm{m}^{-2}\right)$ and the shortest branches at the greatest density $(12.53 \mathrm{~cm}$ at 128plants $\mathrm{m}^{-2}$ ). Although branches in the Fall/Winter growing season were larger, the number of branches was similar for both growing seasons.

The diameter of branches decreased linearly with the increase in plant density. There was a 3\% reduction in Fall/Winter growing season, decreasing, on the average, $2.77 \mathrm{~mm}$ at the lowest plant density, to $1.86 \mathrm{~mm}$ at the greater plant density. In the Spring/ Summer growing season, the reduction was smaller, about $24 \%$, reducing from 2.44 to $1.84 \mathrm{~mm}$ (Figure 2C). Despite the substantial reduction in stem diameter as density increased, there were no undesirable effects on the quality of stems as they did not appear fibrous, inflexible or resistant to handling and transport.

In the fall/Winter growing season, capitulum diameter ranged from $2.23 \mathrm{~cm}$ at the of 48 plants $\mathrm{m}^{-2}$ plant density to $2.03 \mathrm{~cm}$ at 128 plants $\mathrm{m}^{-2}$. These results agree with those reported by NARDI et al. (2001) who also observed a decrease in capitulum diameter of chrysanthemum plants grown with only one flower. However, the Spring/Summer growth season, the results showed a quadratic response (Figure 3A). At the lowest plant density (48plants $\mathrm{m}^{-2}$ ) the diameter was $2.4 \mathrm{~cm}$ and decreased to $2.18 \mathrm{~cm}$ at 80 plants $\mathrm{m}^{-2}$,

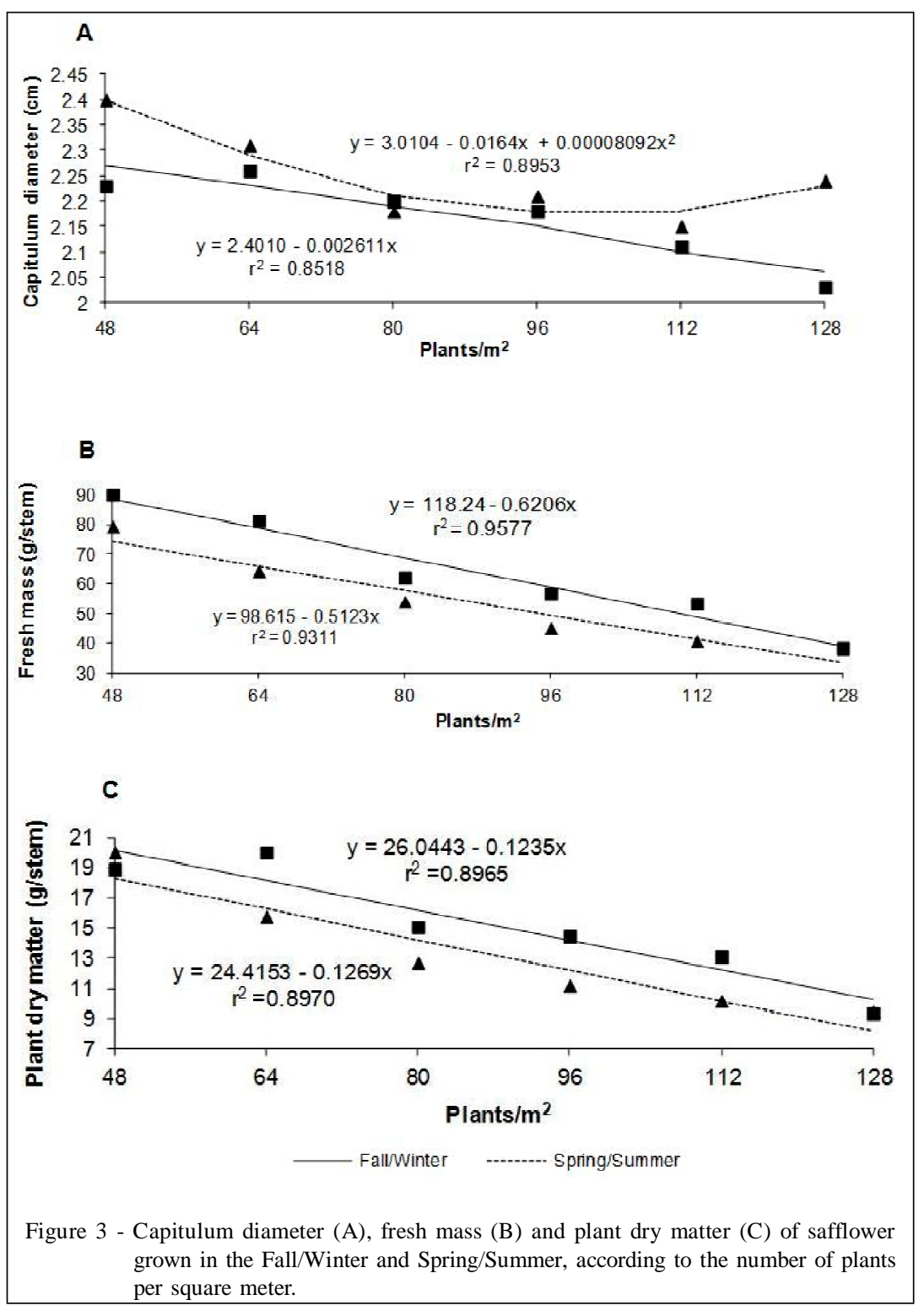

Ciência Rural, v.42, n.12, dez, 2012. 
and increased afterwards. These differences do not represent visual change in size and as a result of the capitulum quality.

Stem fresh weight was reduced when plant density increased regardless of the growing season. At the Fall/Winter growing season, the reduction was $57 \%$, from $90.02 \mathrm{~g}$ at 48 plants $\mathrm{m}^{-2}$ to $38.38 \mathrm{~g}$ at 128 plants $\mathrm{m}^{-2}$. In the Spring/Summer growing season there was a $52.2 \%$, decrease from $79.3 \mathrm{~g}$ at the lowest to $37.9 \mathrm{~g}$ at the greatest plant density (Figure 3B). At Fall/Winter growing season, the stems were greater and heavier compared to ones produced in the Spring/Summer growing season. These results agree with those obtained by HOEVEN et al. (1975) who reported a decrease in the mass of stems of chrysanthemum variety "Spider", when plant density increased from 26plants $\mathrm{m}^{-2}$ to 48 plants $\mathrm{m}^{-2}$ in winter and from 32 plants $\mathrm{m}^{-2}$ to 64 plants $\mathrm{m}^{-2}$ in summer. HOLCOMB \& MASTALERZ (1979) also observed a lower chrysanthemum fresh weight as plant density increased. To obtain a higher number of stems per unit area, the largest populations are those that offer the highest return to the farmers, since the increase in population for this species does not result in increasing the number of stems classified as no sale value.

Individual branch dry matter followed the response of branch fresh mass, that is, in both growing seasons there was nearly $50 \%$ reduction in fresh mass as plant density increased.

In the Fall/Winter growing season, plant dry matter ranged from 18.92g per plant at the lowest density up to $9.34 \mathrm{~g}$ at the greatest plant density. For Spring/Summer season, it ranged from 20.04g at the lowest density up to $9.34 \mathrm{~g}$ at the greatest density (Figure 3C). A similar response was observed by NARDI et al. (2001) in chrysanthemum using plant density from 40 to 104 plants $\mathrm{m}^{-2}$, in which there was a linear decrease of this variable.

The two seasons showed little difference in dry matter and a greater difference for the plant fresh mass, which represented that Fall/Winter season were of heavier plants. The mass differences are due to more water in the plant tissues and dry matter for this crop.

Based on the accumulation of dry matter per area as a function of plant density, it can be inferred that plant density can be increased beyond 128plants $\mathrm{m}^{-2}$, aiming to maximize stem yield and quality, since no weakening of stems effects were observed, especially in the Spring/Summer growing season. However, further research on the effects of plant density on performance of safflower as a cut flower is needed to test this hypothesis.

\section{CONCLUSION}

The increase of the population to 128plants $\mathrm{m}^{-2}$ reduced all analyzed parameters, except the partial height of the plants. The best stems are obtained with the largest population because they have fewer branches, which minimizes the heterogeneity of anthesis between the chapters, in both growing seasons.

\section{REFERENCES}

ANDRIOLO, J.L. Fisiologia das culturas protegidas. Universidade Federal de Santa Maria, Santa Maria: Brasil, 1999. 142p.

BELLÉ, R.A. Caderno didático de floricultura. 3.ed. Santa Maria: RAB, 2008. 181p.

BURKANT, A. Flora ilustrada de Entre Rios (Argentina). Parte VI: Dicotiledôneas metaclamídeas. Buenos Aires: I.N.T.A, 1974. Tomo VI.

DAJUE, L.; MÜNDEL, H. Safflower. Carthamus tinctorius L. Promoting the conservation and use of underutilized and neglected crops. 7. Rome: Institute of Plant Genetics and Crop Plant Research, Gatersleben/International Plant Genetic Resources Institute (IPIGRI), 1996. 83p.

GIAYETTO, O. et al. Comportamiento de cultivares de cártamo (Carthamus tinctorius L.) en la region de Río Cuarto, Córdoba (Argentina). Investigación Agraria: Producción y protección vegetales, Madri, v.14, p.203-215, 1999. Available from: <http:/ /dialnet.unirioja.es/servlet/articulo?codigo $=112256>$. Acessed: Feb. 15, 2010.

HOEVEN, A.P. et al. Plant density of year - Round chrysanthemums. Netherlands Journal of Agricultural Science, Netherlands, v.23, p.224-230, 1975. Available from: <http://www.scielo.br/ scielo.php?script $=$ sci_nlinks\& $r$ f $=000067 \&$ pid $=$ S0 103 $8478200100060000600003 \& \operatorname{lng}=$ en>. Acessed: Mar. 10, 2010.

HOLCOMB, E.J.; MASTALERZ, J.W. Spacing key growth factor affecting greenhouse mums. Science in Agriculture, Pennsylvania, v.27, p.4-5, 1979. Available from: <http://www.scielo.br/ scielo.php? script $=$ sci_nlinks\&ref $=000068 \&$ pid $=$ S0 103 8478200100060000600004\&lng=en>. Acessed: Mar. 2, 2010.

MARTINS, J.D. et al. Plastocrono e número final de nós de cultivares de soja em função da época de semeadura. Ciência Rural, Santa Maria, v.41, n.6, p.954-959, 2011. Available from: <http://www.scielo.br/scielo.php?pid=S0103-847820 $11000600006 \&$ script=sci_abstract\&tlng=pt $>$. Acessed: Jan. 3, 2010. doi: 10.1590/S0103-84782011005000064.

MULLER FLOWERSEEDS. Variety and pricelist for professional flowergrowers. Lisse: Holland, 1998. 68p.

NARDI, C. et al. Qualidade de crisântemo (Dendranthema grandiflora Tzvelev.) cultivar 'Snowdon' em diferentes populações e épocas de plantio. Ciência Rural, Santa Maria, v.21, p.957-961, 2001. Available from: <http://www.scielo.br/ scielo.php? script $=$ sci_arttext\&pid $=$ S0103-84782001000 
600006>. Acessed: Fev. 15, 2010. doi: 10.1590/S010384782001000600006 .

OELKE, E.A. et al. Alternative field crops manual: safflower. 8p. Available from: <www.hort.purdue.edu/newcrop/ afcm/safflower.html>. Acessed: Jul. 21, 2010.

OLIVEIRA, G.G. Trichoderma spp. no crescimento vegetal e no biocontrole de Sclerotinia sclerotiorum e de patógenos em sementes de cártamo (Carthamus tinctorius). 2007. 80f. Dissertação (Mestrado em Agronomia) - Universidade Federal de Santa Maria, RS.
SAKATA Seeds. Disponível em: <www.sakata.com/ product_flower.aspx ?CategoryId $=4 \&$ SpeciesId $=88 \&$ VarietyId $=200>$. Acesso em: Jul. 17, 2010.

SNIJBLOEMENKATALOGUS, H. Bloemzaden B.V. Ambacht H.I. Holland, 1996. 48p.

STRECK, N.A. et al. Estimating leaf appearance rate and phyllochron in safflower (Carthamus tinctorius L.). Ciência Rural, Santa Maria, v.35, p.1448-1450, 2005. Available from: <http://www.scielo.br/scielo.php?script=sci_arttext\&pid=S010384782005000600036>. Acessed: Jul. 21, 2010. doi: 10.1590/ S0103-84782005000600036. 